\title{
Comparison of mathematical methods and measurements of traffic noise indices in pedestrian routes
}

\author{
Comparação de métodos matemáticos e medidas de \\ índices de poluição sonora em rotas de pedestres
}

\section{Guillermo Angel Perez Lopez \\ Léa Cristina Lucas de Souza}

\begin{abstract}
- $\mathrm{n}$ this study, we propose an analysis of the vehicular traffic noise indices and comparison between field measurements and prediction data obtained from mathematical models. The study area consists of two pedestrians routes of a medium-sized South American city.

University students use these routes in displacements between their universities and residences. We monitored twenty-eight points along the two routes, performing three daytime measurements for each point. The calculated values were obtained from two mathematical predicted models: the English model CRTN (Calculation of Road Traffic Noise) and the French model NMPB-Routes (Nouvelle Methode de Prevision de Bruit). The measurements considered two noise descriptors: the A-weighted equivalent sound level $\left(\mathrm{L}_{\text {Aeq }}\right)$ and the noise pollution index $\left(\mathrm{L}_{\mathrm{np}}\right)$. The results show that the pedestrians are exposed to excessive levels of vehicle traffic noise along these routes. However, the analysis showed that the two mathematical models achieved good similarity and high performance in the prediction potential. The CRTN model has a better performance than NMPB, proving to be useful as an auxiliary tool in the monitoring of vehicle traffic noise. Finally, we used the CRTN ( $\mathrm{L}_{\text {Aeq }}$ ) predictions to generate the map of noise pollution indices.

Keywords: Road traffic. Noise map. Prediction model. Acoustic comfort. CRTN. NMPB.

\section{Resumo}

Neste trabalho nós propomos uma análise dos índices do tráfego de ruído veicular e uma comparação entre medições de campo e dados de previsões obtidas de modelos matemáticos. A área de estudo são duas rotas de pedestres, de uma cidade sul-americana de médio porte. Estudantes universitários utilizam essas rotas nos deslocamentos entre suas universidades e seus lugares de moradia. Nós monitoramos vinte e oito pontos ao longo das duas rotas, realizando três medições diurnas para cada ponto. Os valores calculados foram obtidos utilizando dois modelos de previsão matemática: o modelo inglês CRTN (Cálculo do Ruído de Trânsito Rodoviário) e o modelo francês NMPB-rotas (Nouvelle Methode de Prevision de Bruit). As medidas consideraram dois descritores de ruído: o nível de ruído contínuo equivalente $\left(L_{\text {Aeq }}\right)$ e o índice de poluição sonora $\left(L_{n p}\right)$. Os resultados mostram que os

${ }^{1}$ Guillermo Angel Perez Lopez ${ }^{1}$ Universidade Federal de São Carlos São Paulo - SP - Brasil

${ }^{2}$ Léa Cristina Lucas de Souza ${ }^{2}$ Universidade Federal de São Carlos São Carlos - SP - Brasil

pedestres estão expostos a níveis excessivos de ruído veicular ao longo dessas rotas. De outro lado, a análise mostrou que os dois modelos matemáticos alcançaram boa similaridade e bom desempenho no potencial de previsão. $O$ modelo CRTN teve melhor desempenho do que NMPB, demonstrando ser útil como ferramenta auxiliar no monitoramento do ruído de tráfego veicular. Nós utilizamos as previsões $C R T N\left(L_{\text {Aeq }}\right)$ para gerar o mapa dos índices de poluição sonora.
\end{abstract}

Recebido em 31/12/18 Aceito em 29/06/19
Palavras-chave: Ruído de tráfego. Mapa de ruído. Modelo de predição. Conforto acústico. CRTN. NMPB. 


\section{Introduction}

Human movement is often related to noise production. In particular, when generated by vehicular flow, noise may affect human health (ANCONA et al., 2017; MÜNZEL et al., 2018). Additionally, vehicular noise emissions combined with the urban configuration of buildings and surfaces may even enlarge human noise annoyance (PEREZ; PENTEADO; SOUZA, 2017; SUN et al., 2018), because of the increase on the noise ray reflections during sound propagation. Furthermore, these risks increase with the exposure of time, as in the case of people exposed to the vehicular flow by having to ride a bicycle or walk on urban streets (VAN SCHALKWYK; MINDELL, 2018; NIEUWENHUIJSEN, 2018). Even along preserved cultural and heritage urban routes, with some restriction to vehicular flow, the excessive traffic noise may lead to human acoustical discomfort, as demonstrated by Sheng and Tang (2015).

Traditionally, acoustic discomfort is studied through numerical expressions and calculations, which by themselves may lack spatial information necessary for the analysis of urban areas and their social aspects. Within this context, a noise map is a feasible solution, if combined with adequate mathematical models. When appropriated techniques are applied, noise maps allow the extraction of valuable spatial information, as shown by Pérez López and Souza (2018).

On the other hand, a construction of noise maps, exclusively based on field measurements, may need multiple tasks that would make it unfeasible. Alternatively, indirect measurements by means of calculation models may help filling the existing gaps or inexistence of data. Based on accessible variables, such as vehicular flow, speed limit, type of road and vehicular composition, some of the available models are adapted to specific sites, such as: the Japanese model, ASJ Model-1993 (SAKAMOTO, 2015); the United States Federal Railway Administration Traffic Noise Model (ANDERSON; BARRETT, 2014); or the Nordic Prediction Method for Train Noise Model (NMT) (CHANG et al., 2012). CRTN - Calculation of Road Traffic Noise (DOT UK, 1988) and NMPB - Nouvelle Méthode de Prévision du Bruit des Routes (DUTILLEUX et al, 2010) are also two examples of these kinds of models. Studies have shown that these models may present a good correlation between measured and calculated data (SHENG; XU; LI, 2015; DI et al., 2018; BRITO et al, 2018).

For South-American urban areas, though, the validation of prediction models is far from being easily applicable. There is a gap among new technologies, economy and governance, which demands effective actions for a fast acquisition of information about the urban environment. Thus, seeking alternative solutions is an urgent action for reaching a better quality of life in these kinds of cities.

We propose an analysis of traffic noise levels for two pedestrian routes. In addition, we explore two mathematical prediction methods CRTN and NMPB. We established 28 control points along the routes, and monitor vehicle traffic noise as part of the mobility conditions. For these points, we carry out comparative assessments of forecast values and field measurements. The evaluation of the CRTN and NMPB may present an option for the continuous monitoring of vehicle traffic noise, in cities that prefer to waive the use of infrastructure.

\section{Method}

The method here applied consisted of four processes: the delimitation of the routes; data collection; comparative analysis; and, application and assessment of the model chosen within the noise map. The delimitation corresponded to the phase of selecting relevant urban routes as study samples. The data collection was the step of measurements to characterize these routes. The analysis process established a measured and calculated comparison of the values obtained by CRTN and NMPB models. Finally, the application phase considered the best-fit model for the development of a noise assessment map.

\section{Delimitation of Routes in the study area}

The study area is the city of São Carlos, in the central region of the State of São Paulo, Brazil. (Figure 1), which has an estimated population of 249.415 inhabitants (IBGE, 2018).

Two routes, showed in Figure 2, were selected for measurements of vehicular flow, traffic speed, traffic distribution, and sound pressure levels. These routes are usually a daily-path for university students or users, by foot, bicycle, cars or buses. 
Figure 1 - Study area: urban area of São Carlos, State of São Paulo, Brazil

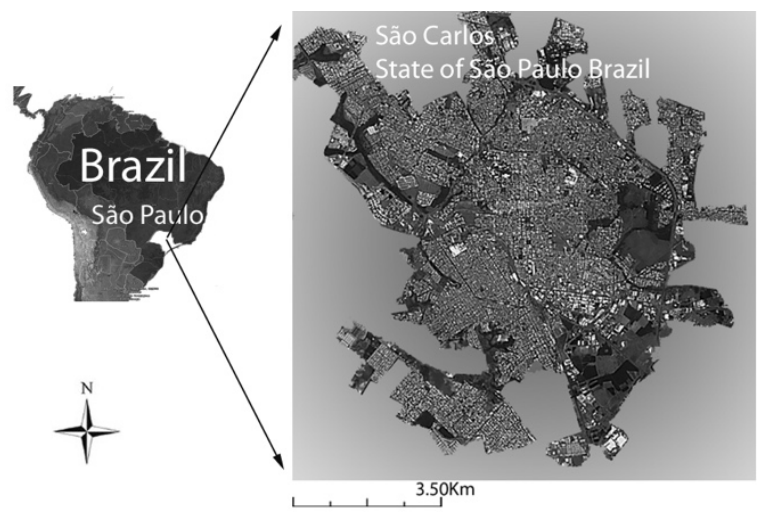

Figure 2 - The routes studied and location of the 28 points of measurements - in addition, distribution of four types of roads around the two routes

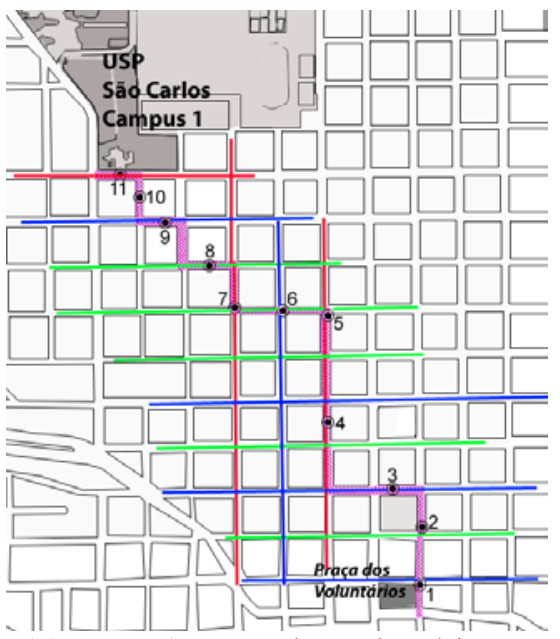

(a) Route 1, Praça dos voluntáriosUSP campus $1,1.5 \mathrm{~km}$

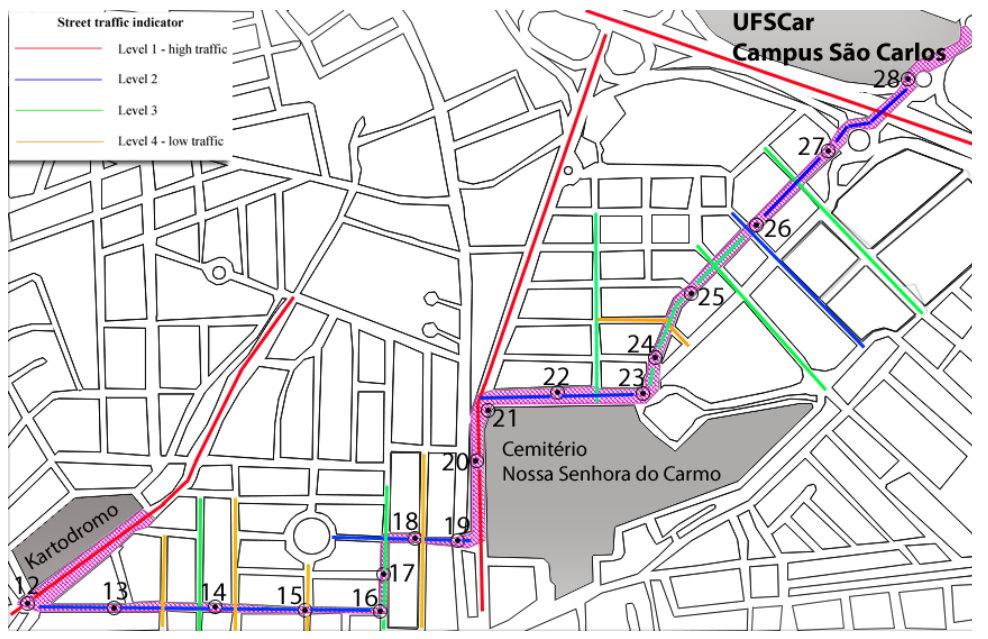

(b) Route 2, Kartódromo-UFSCar, $2.8 \mathrm{~km}$

Both routes begin in areas where there is a high concentration of student residences and each one ends in one University Campus (Route 1 is a link to the University of São Paulo and Route 2 is a link to the Federal University of São Carlos), crossing commercial areas. The extensions of these routes are $1.5 \mathrm{~km}$ and $2.8 \mathrm{~km}$, respectively. The streets near each measurement point were classified into four types. Figure 2 shows the level of traffic associated with a color in the map: level 1 (red), those that communicate the main sectors of the cities and have a high traffic level; level 2 (blue), streets with heavy car traffic, medium high traffic level; level 3 (green), streets with low average traffic; level 4 (yellow), greened area streets with low traffic level. This classification is based on the average number per hour and the type of vehicles transit through each road, data obtained by real-time monitoring cameras. Information provided by the transport and transit office of the city of São Carlos.

\section{Data collection}

The control points at the routes were references for traffic data collection (flow, speed and distribution) and sound pressure levels. The traffic data were provided by the Municipal Traffic Department, while the sound pressure levels were measured in-site. The measurements were taken at peak hours of vehicles flow in three periods, from 7:00 to 8:00, from 11:30 to $12: 30$ and from 17:30 to 19:00; on Tuesdays, Wednesdays and Thursdays avoiding special conditions of weekends and holidays.

A sound pressure meter Analyzer 2270-L from Brüel and Kjaer, which is a hand-held type and precision class 1, was applied for registering the sound pressure levels. The analyzer was set up to follow the current Brazilian Standards suggested by NBR 10.151 (ABNT, 2019) and ISO 1996: Curve A (dB) and slow response. After 
calibration with a sound level calibrator, measurements were taken during 5 min of integration, at least 2 meters far from reflexive surfaces and 1.5 above ground level. The variables obtained for each control point were the equivalent sound pressure level $\left(\mathrm{LA}_{\mathrm{eq}}\right)$, the peak sound level $\left(\mathrm{L}_{10}\right)$ and the background noise level (L90).

In addition, the noise pollution index $\left(\mathrm{L}_{\mathrm{np}}\right)$ was determined for an analysis of the noise conditions at the routes. When a city is supported by a continuous sound monitoring network, the $L_{\text {den }}$ (an index that integrates 24hours of sound levels monitored during the day, evening and night) is the most common index applied. However, a manual data collection is a time consuming process, which makes the $\mathrm{L}_{\mathrm{den}}$ an almost unfeasible index for the case under study. Therefore, the noise pollution index $\mathrm{L}_{\mathrm{np}}$, expressed by Equation 1 (BIES; HANSEN, 2009), was computed for each control point, generating values of $L_{n p_{a}}\left(L_{10}, L_{90}, a\right)$, where, $a=$ $L_{\text {Aeq }}($ measured $), L_{\text {Aeq }}(C R T N), L_{\text {Aeq }}(N M P B)$.

$L_{n p}=L_{A e q}+\left(L_{10}-L_{90}\right)$

Eq. 1

The advantage of applying this index is the correlation kept for the subjective disturbance that the human being perceives related to the fluctuation of sound (AGARWAL et al., 2017), which is expressed by the computed difference between $\mathrm{L}_{10}$ and $\mathrm{L}_{90}$ in the Equation 1. This difference could be also called Noise Climate (HUNASHAL; PATIL, 2012).

\section{Analysis process}

Two models were submitted to an analysis process: the English model CRTN and the French model NMBPRoute 2008. For the CRTN model, a linear sound source and a constant traffic speed is considered for the calculation of the sound pressure level (L). The mathematical expression of this model is described by Equation 2 (DOT UK, 1988) and the variables in Table 1.

$L=L_{0}+A_{H V}+A_{G}+A_{a}+A_{B}$

For the NMPB-Route model (DUTILLEUX et al., 2010) the sound pressure level (L_(A,C)), generated by a sound source $(S)$, at a distance $(d)$ of a receptor $(R)$, in a propagation condition (C), is calculated by means of the mathematical expression in Equation 3, for which the variables are described in Table 2.

L_(A,C)=L_w-(A_div+A_atm+A_(bnd,C))

Table 1 - Description of variables in the equation of CRTN model

\begin{tabular}{|c|c|c|c|}
\hline Variable & Meaning & Equation & \\
\hline$L_{0}$ & $\begin{array}{l}\text { the basic noise emission } \\
\text { level }\end{array}$ & $\begin{array}{l}\qquad L_{0}=42.2+10 \log _{10}(q) \\
\text { where } q \text { is the hourly flow of all vehicles }\end{array}$ & Equation 3 \\
\hline$A_{H V}$ & $\begin{array}{l}\text { the adjustment for mean } \\
\text { traffic speed and } \\
\text { percentage of heavy } \\
\text { vehicles }\end{array}$ & $\begin{array}{l}\qquad A_{H V} \\
=33 \log _{10}\left(V+40+\frac{500}{V}\right)+10 \log _{10}\left(1+\frac{5 P}{V}\right)-68.8 \\
\text { where } V \text { is the traffic speed and } P \text { is the percentage of } \\
\text { heavy vehicles }\end{array}$ & Equation 4 \\
\hline$A_{G}$ & $\begin{array}{l}\text { is the adjustment for } \\
\text { gradient of roadway }(G)\end{array}$ & $A_{G}=\left[0.73+\left(2.3-\frac{1.15 P}{100}\right) \cdot \frac{P}{100}\right] \cdot G$ & Equation 5 \\
\hline$A_{a}$ & $\begin{array}{l}\text { is the correction for } \\
\text { angle of view }(\theta)\end{array}$ & $A_{a}=10 \log _{10}\left(\frac{\theta}{180}\right)$ & Equation 6 \\
\hline$A_{B}$ & $\begin{array}{l}\text { is the potential barrier } \\
\text { correction }\end{array}$ & $\begin{array}{l}A_{B}=a_{0}+a_{1} X+a_{2} X^{2}+\cdots+a_{n} X^{n} \\
\text { where } a_{0} \text { and } a_{n} \text { area constants, while } X=\log _{10} S \text { is the } \\
\text { path length difference, in meters, between the direct and } \\
\text { diffracted rays }\end{array}$ & Equation 7 \\
\hline
\end{tabular}

Table 2 - Description of variables in the equation of NMPB-Routes model

\begin{tabular}{c|lll}
\hline Variable & \multicolumn{3}{|c}{ Meaning } \\
\hline$L_{w}$ & the level of the acoustical power of S & \\
\hline$A_{\text {div }}$ & the geometric divergence & $A_{\text {div }}=20 \log _{10} d+11$ & \\
\hline$A_{\text {atm }}$ & the atmospheric absorption & & \\
\hline$A_{\text {bnd,C }}$ & the attenuation due to ground effects (bnd) and meteorological conditions \\
\hline
\end{tabular}


For the analysis of both models, traffic was considered as the only noise source of the environment. The traffic flow was divided into light vehicles and heavy vehicles. The input of light vehicles corresponded to the number of small vans, taxis, private vehicles and motorcycles, while the input for heavy vehicles were the number of trucks and buses.

We implemented an algorithm for CRTN model in a spreadsheet for the $\mathrm{L}_{\text {Aeq }}$ calculation and $\mathrm{L}_{\mathrm{np}}(\mathrm{CRTN})$ values, while commercial software (CadnaA) was applied for the calculation of $L_{\text {Aeq }}(N M P B)$ and $L_{n p}(N M P B)$ values.

Afterwards, a comparison between calculated and measured values was performed. We calculated the mean $\mathrm{L}_{\text {Aeq }}$ and $\mathrm{L}_{\mathrm{np}}$ values from the three values measured in the diary at each point. We compared these mean values for the same parameters calculated at the same point by CRTN and NMPB models. We made these comparisons using the calculation of the absolute error percentage and a regression analysis of the correlation coefficient $\left(\mathrm{R}^{2}\right)$ as evaluation criterion.

\section{Applying the best-fit model for noise map construction}

Instead of applying the best-fit model only to calculate the $L_{\text {Aeq, }}$, the proposal here was to apply values of $L_{n p_{a}}$ to develop a ready-to-read-map of the noise pollution index. In general, noise maps are usually appropriate tools for planning purposes, because of their visual communication potential. These maps are able to highlight conflict areas, as well as, to offer the spatial distribution of the noise.

By applying the best-fit model, $\mathrm{L}_{\mathrm{np}}$ could be calculated for any other point or route, filling gaps of data. Then, each of these values was incorporated as a linear sound source input to the Cadna-A software; information regarding the Cadna-A configuration parameters can be obtained in the work of Zhang et al. (2016). Finally, an interpolation of $L_{n p}$ values was performed and the noise pollution index map of both routes was created.

\section{Results}

The results for the analysis process and the noise conditions assessment are presented, followed by a discussion for future approaches.

\section{Analysis of the models}

Three on-site measurements were taken from every point: morning (7:00 to 8:00), noon (11:30 to 12:30) and afternoon (17:30 to 19:00). All measurements correspond to daytime schedules, with each point having its three measurements on the same day. The predicted CRTN and NMPB, and measurements values' comparison for the Router 1 are shown in Figures 3 and 4.

Figures 3 and 4 show that:

(a) the measured values of $\mathrm{L}_{\text {Aeq }}(\min , \max )=(66.1,79.1) \mathrm{dB}$ and $\mathrm{L}_{\mathrm{np}}(\min , \max )=(75.0,97.3) \mathrm{dB}$, these values are very high and they are well above the critical limit (60dB); and

(b) the measured noise is more intense in the afternoon and noon, presenting great differences from the morning period.

Route 2 comparison values are shown in Figures 5 and 6.

Figures 5 and 6 show that:

(a) the measured values of $\mathrm{L}_{\text {Aeq }}(\min , \max )=(63.9,78.8) \mathrm{dB}$ and $\mathrm{L}_{\mathrm{np}}(\min , \max )=(72.0,93.4) \mathrm{dB}$, again these values are very high and they are well above the critical limit (60dB); and

(b) once again, the measured noise is more intense in the afternoon and noon, presenting great differences from the morning period.

Exposure to noise has been associated with health disorders, with critical levels ranging from 70 to $100 \mathrm{~dB}$ (MÜNZEL et al., 2018). In this range, threshold values can be classified as:

(a) moderate (greater than $65 \mathrm{~dB}$ ), several moderate (greater than $75 \mathrm{~dB}$ ); and

(b) severe (greater than $85 \mathrm{~dB}$ ).

Table 3 shows occurrences summary in noise levels, based on Figures 3, 4, 5 and 6. 
Figure 3 - $L_{\text {Aeq }}$ from Route 1

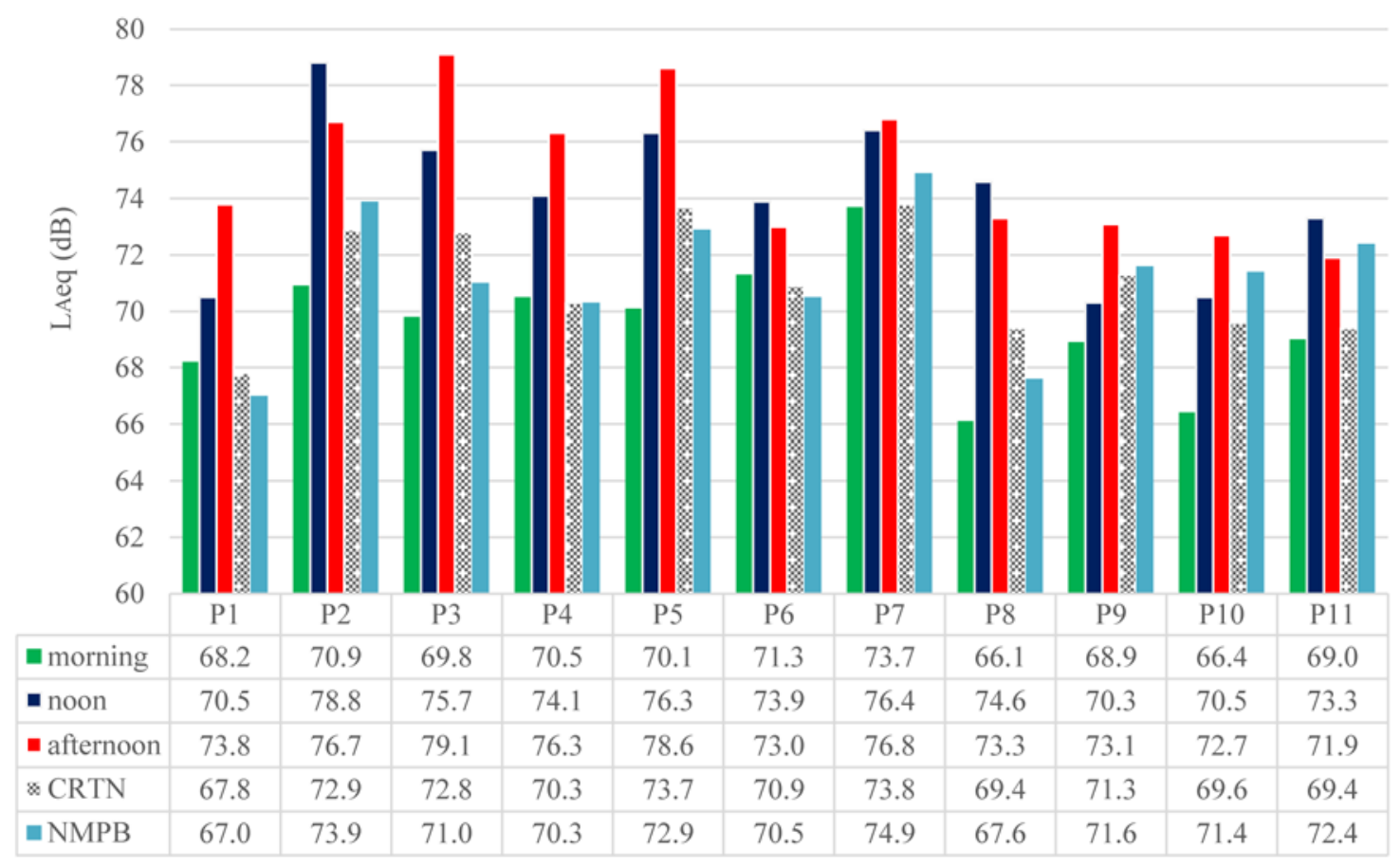

Figure 4 - $\mathbf{L}_{n p}$ from Router 1

100

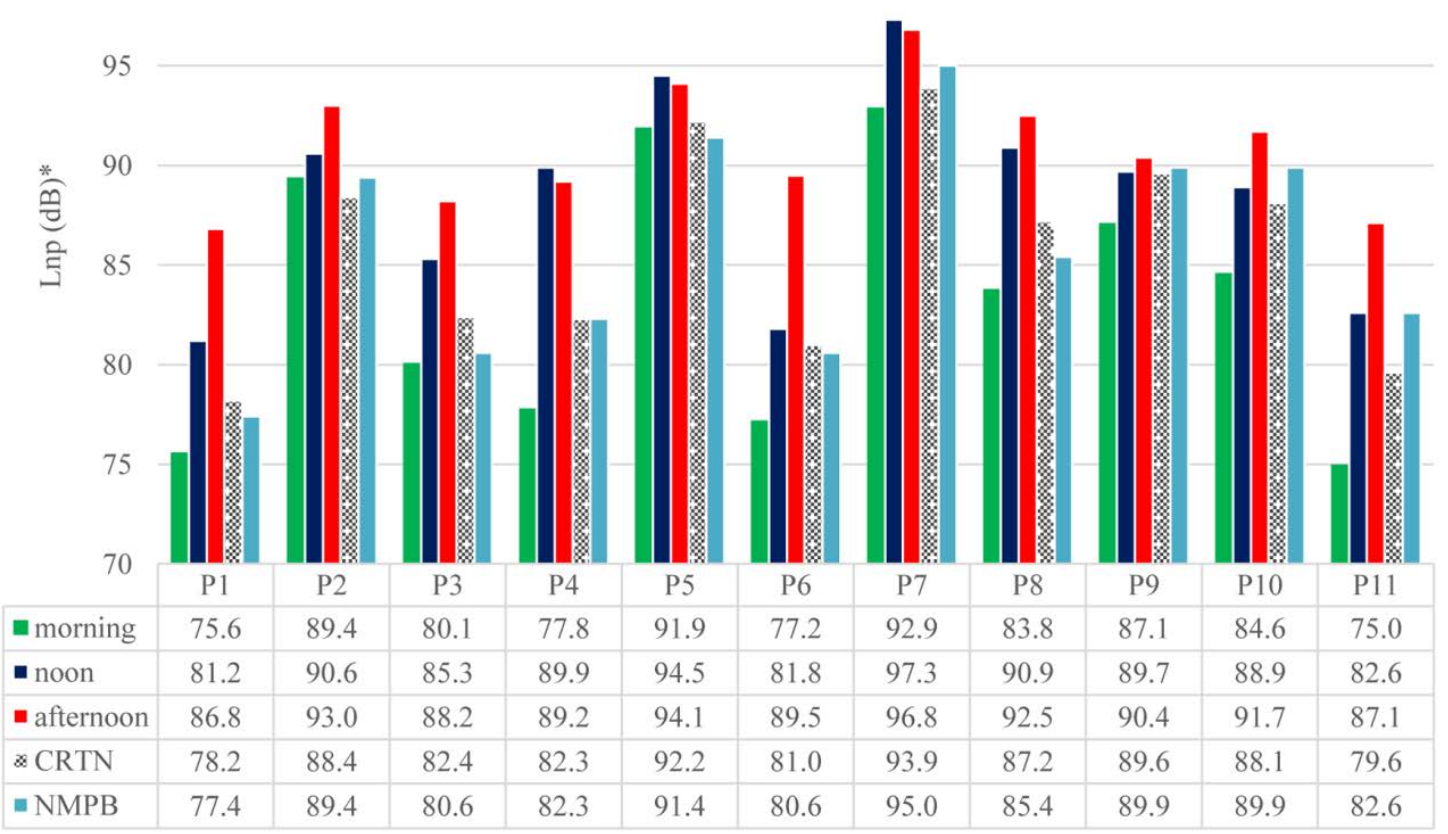

Nota: *all Lnp values, throughout this work, are A-weighted. 
Figure 5 - $\mathbf{L}_{\text {Aeq }}$ from Router 2

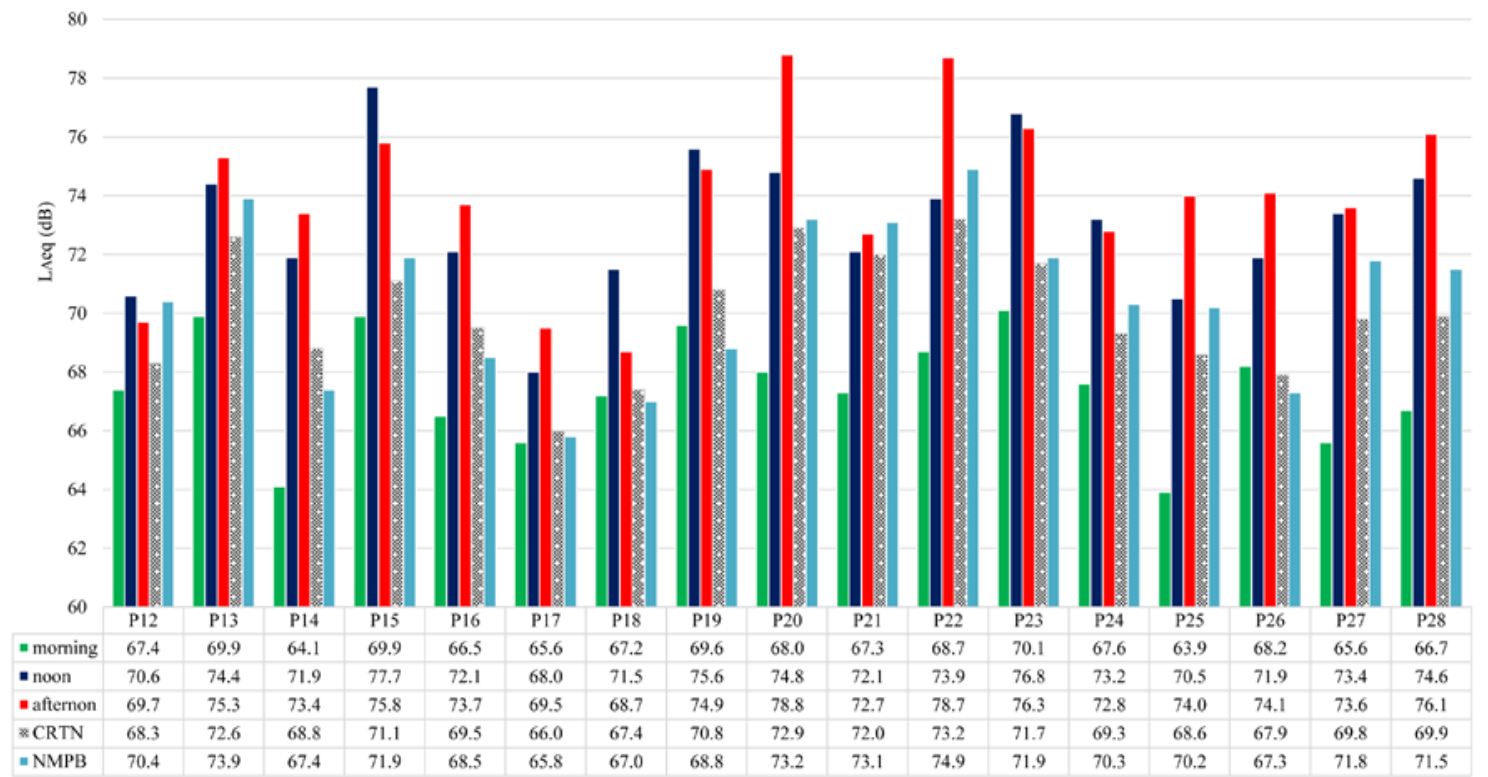

Figure 6 - $L_{n p}$ from Router 2

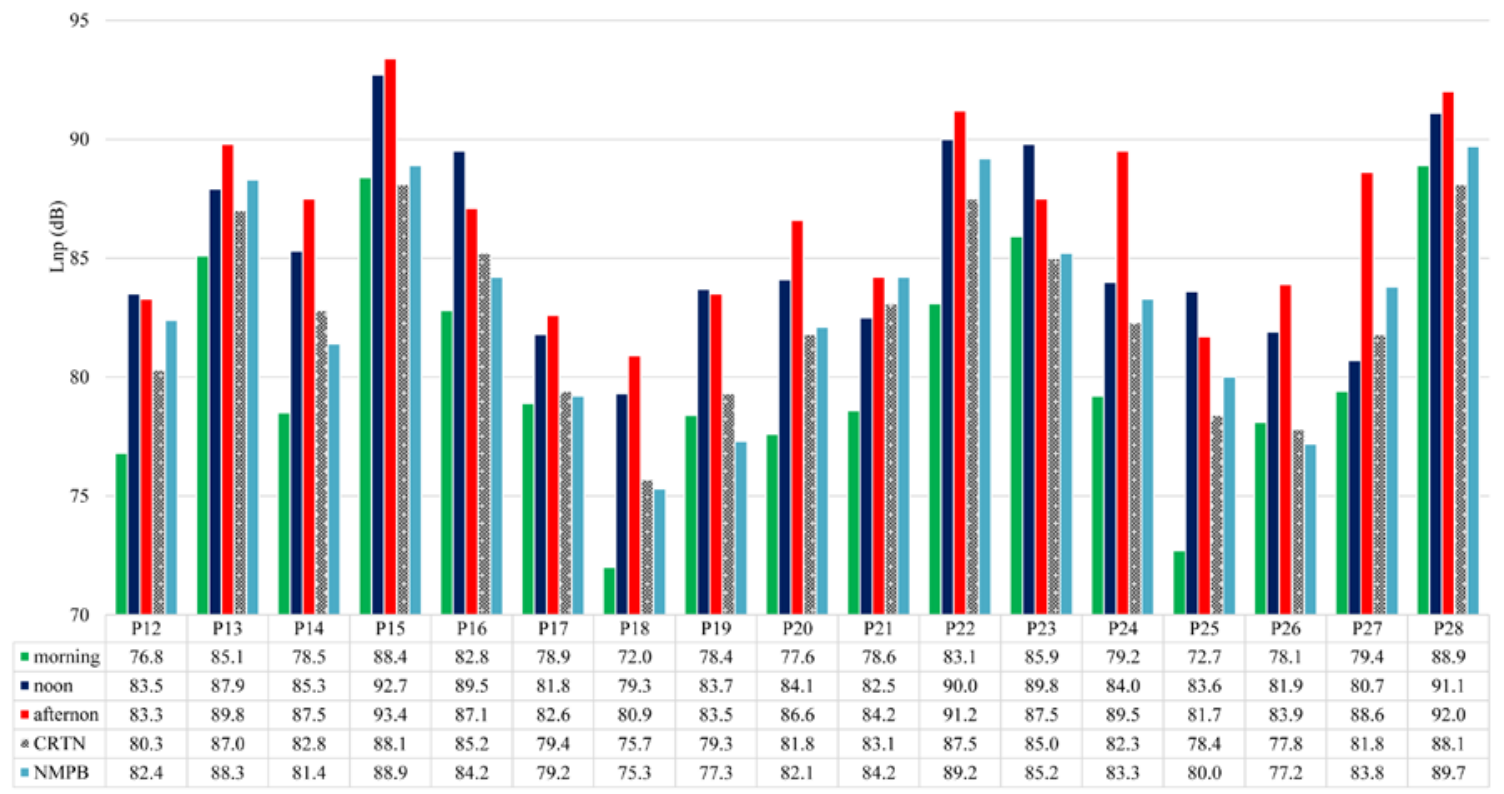

Table 3 - Occurrences of moderate and unhealthy levels, in the Routes 1 and 2

\begin{tabular}{lrcrl|rlrl}
\hline \multirow{2}{*}{ schedules } & \multicolumn{4}{c}{ LAeq (dB) } & \multicolumn{4}{c}{ Lnp (dB) } \\
& $>=65$ & $(\%)$ & $>=75$ & $(\%)$ & $>=75$ & $(\%)$ & $>=85$ & $(\%)$ \\
\hline morning & 26 & $(92.9)$ & 0 & $(0.0)$ & 26 & $(92.9)$ & 8 & $(28.6)$ \\
noon & 28 & $(100.0)$ & 7 & $(25.0)$ & 28 & $(100.0)$ & 15 & $(53.6)$ \\
afternoon & 28 & $(100.0)$ & 11 & $(39.3)$ & 28 & $(100.0)$ & 21 & $(75.0)$ \\
\hline
\end{tabular}

Table 3 shows that:

(a) morning period is the only one that presents $L_{\text {Aeq }}$ values in moderate noise level;

(b) at least $8 \%$ of the $\mathrm{L}_{\mathrm{np}}$ values in the morning are considered sevee; 
(c) at least $7 \%$ of the $\mathrm{L}_{\text {Aeq }}$ values are considered severe moderate and $15 \%$ of the $\mathrm{L}_{\mathrm{np}}$ are considered severe in the noon period;

(d) in the afternoon period, at least $11 \%$ of the $\mathrm{L}_{\text {Aeq }}$ are considered several and $21 \%$ of the $\mathrm{L}_{\mathrm{np}}$ are considered severe levels.

Table 4 shows the calculated values of the minimum and maximum absolute error of the CRTN and NMPB for the measured values.

Table 4 shows that:

(a) CRTN (lower min, higher max) absolute error are $\mathrm{L}_{\text {Aeq }}(0.14,8.37)$ and $\mathrm{L}_{\mathrm{np}}(0.12,9.91)$;

(b) NMPB (lower min, higher max) absolute error are $L_{\text {Aeq }}(0.29,10.25)$ and $L_{n p}(0.00,10.83)$;

(c) CRTN (min, max) absolute error are $L_{\text {Aeq }}(0.14,7.36)$ period and $L_{n p}(0.33,7.85)$ both in the morning; and

(d) NMPB (min, max) absolute error are $L_{\text {Aeq }}(0.29,9.39)$ and $L_{n p}(0.00,8.46)$ both in the afternoon period.

Relationship analysis among in-site-measure and calculated values are shown in Figures 7, 8, 9, and 10.

The correlation values could be classified as: negligible correlation ( 0 to 0.3$)$, weak correlation ( 0.3 to 0.5$)$, moderate correlation ( 0.5 to 0.7$)$, strong correlation ( 0.7 to 0.9$)$ and very strong ( 0.9 to 1$)$. Table 5 shows the correlation values summary from Figures 7, 8, 9 and 10.

Table 5 results suggest that:

(a) CRTN correlation to the measured values is a weak correlation (1 value), moderate correlation (2 values) and strong correlation (3 values);

(b) NMPB correlation to the measured values is a negligible correlation (1 values), weak correlation (2 values) and strong correlation (3 values);

(c) $\mathrm{L}_{\text {Aeq }}$ measured values and correlation for CRTN and NMPB are low; and

(d) all $\mathrm{L}_{\mathrm{np}}$ correlation values have a strong correlation.

Table 4 - CRTN and NMPB absolute error for measured values, in Routes 1 and 2

\begin{tabular}{|c|c|c|c|c|c|c|c|}
\hline & \multicolumn{3}{|c|}{ LAeq absolute error (\%) } & \multicolumn{4}{|c|}{ Lnp absolute error (\%) } \\
\hline & CRTN & \multicolumn{2}{|c|}{ NMPB } & \multicolumn{2}{|c|}{ CRTN } & \multicolumn{2}{|c|}{ NMPB } \\
\hline & $\min \max$ & $\min$ & $\max$ & $\min$ & $\max$ & $\min$ & $\max$ \\
\hline morning & $0.14 \quad 7.36$ & 0.29 & 9.86 & 0.33 & 7.85 & 0.00 & 10.14 \\
\hline noon & 0.148 .50 & 0.29 & 9.39 & 0.12 & 8.46 & 0.00 & 8.46 \\
\hline afternoon & 0.978 .37 & 0.56 & 10.25 & 0.89 & 9.91 & 0.00 & 10.83 \\
\hline
\end{tabular}

Figure 7 - $\mathrm{L}_{\text {Aeq }}$ values, relationship between measured and CRTN values

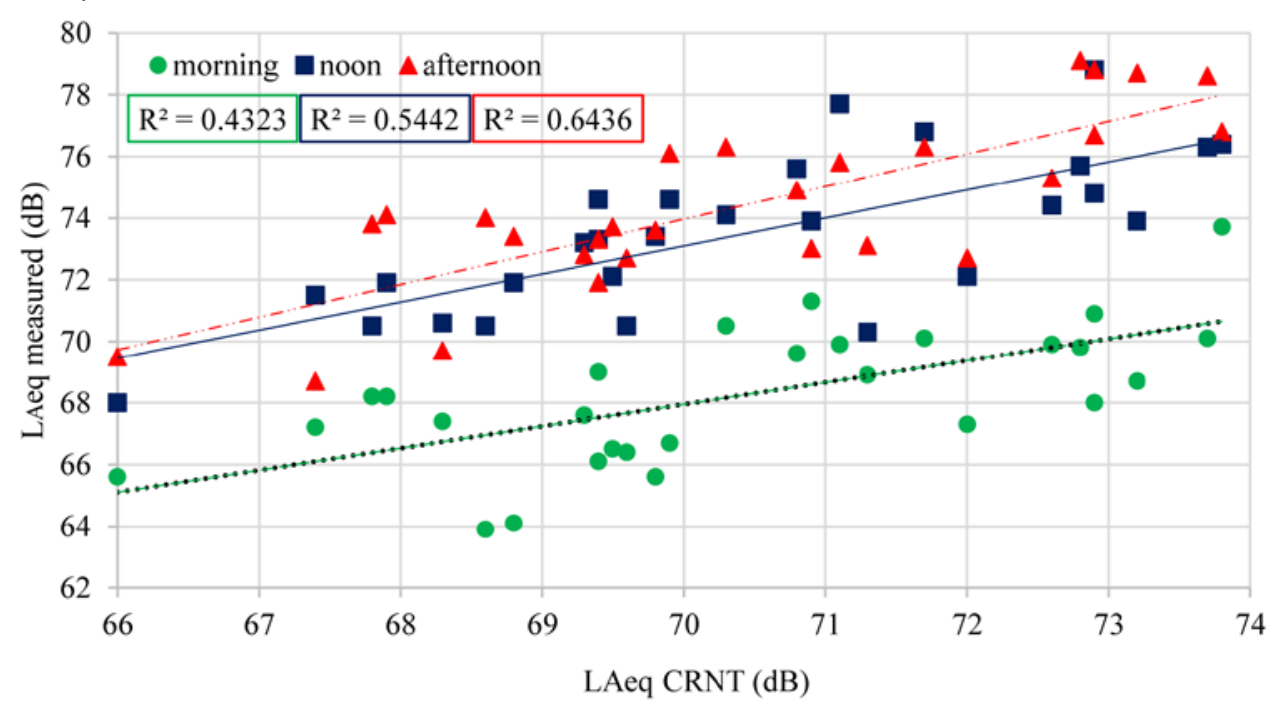


Figure 8 - $L_{n p}$ values, relationship between measured and CRTN values

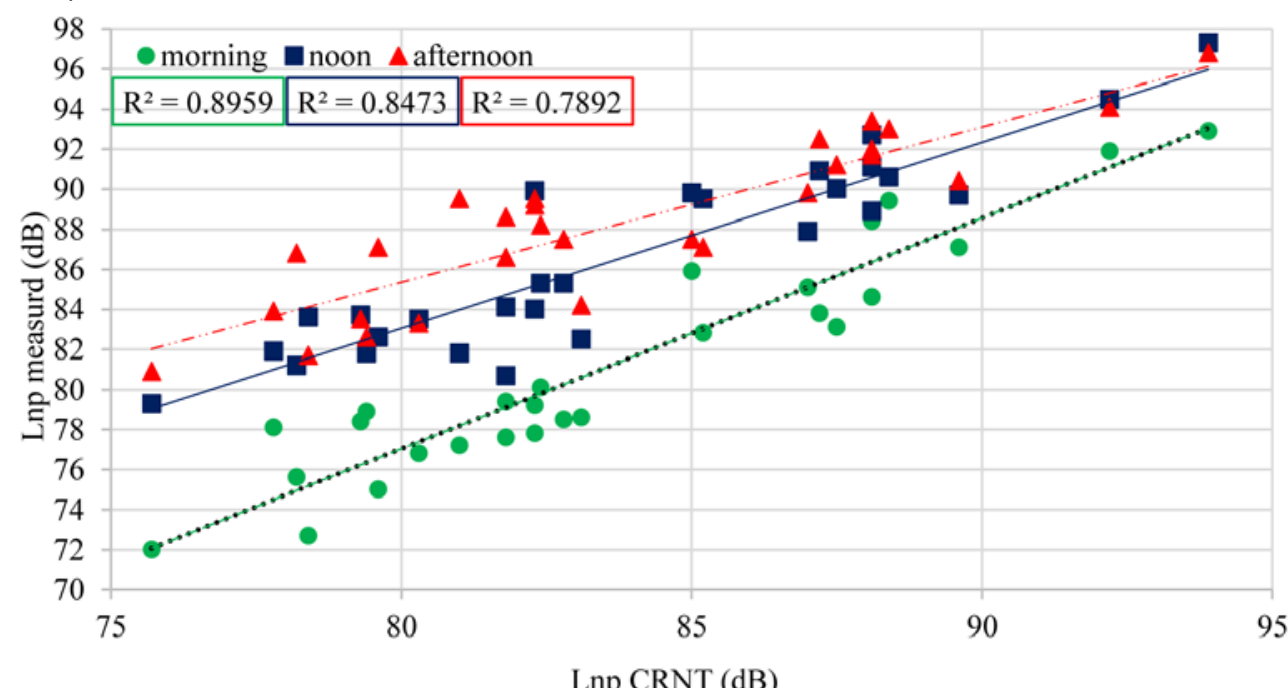

Figure 9 - $L_{\text {Aeq }}$ values, relationship between measured and NMPB values

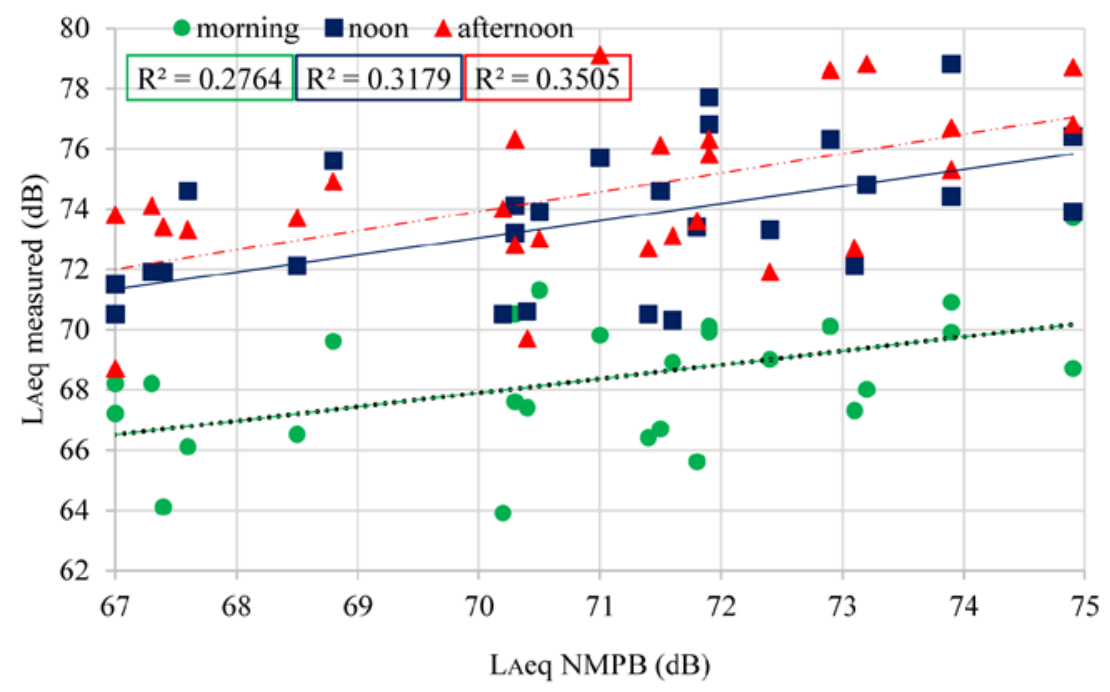

Figure $10-L_{n p}$ values, relationship between measured and NMPB values

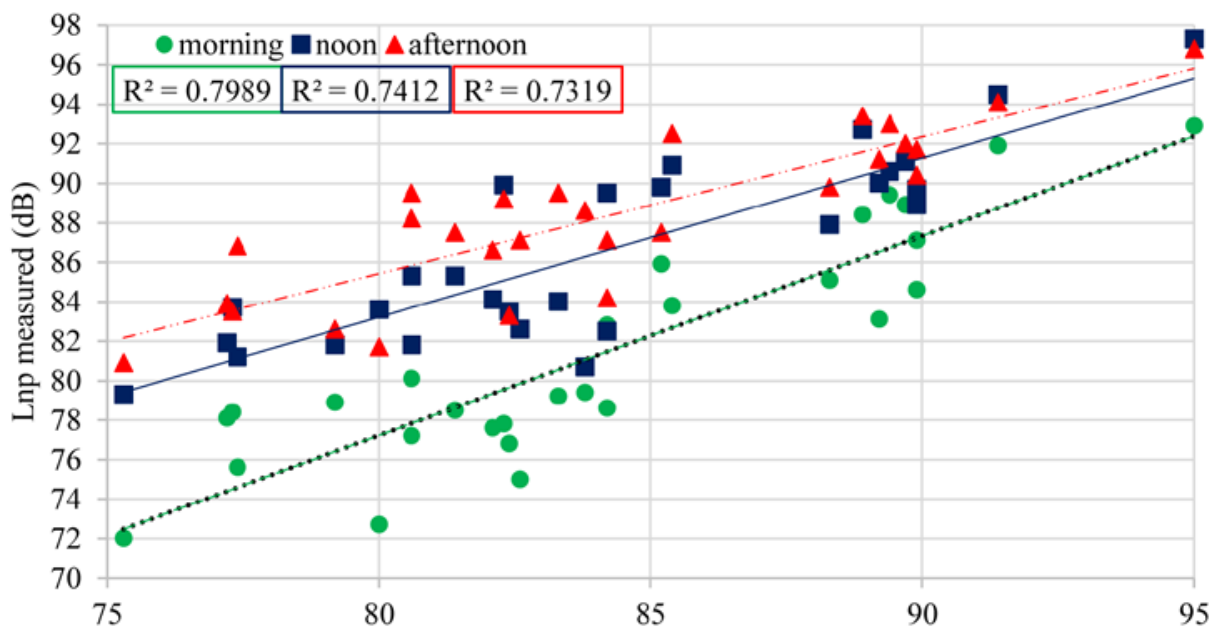

Lnp NMPB (dB) 
Table 5 - CRTN and NMPB correlation values $\left(\mathbf{R}^{\mathbf{2}}\right)$

\begin{tabular}{|c|c|c|c|c|c|c|}
\cline { 2 - 7 } \multicolumn{1}{c|}{} & \multicolumn{3}{c|}{ LAeq R $^{2}$} & \multicolumn{3}{c|}{ Lnp R $^{2}$} \\
\hline morning & noon & afternoon & morning & noon & afternoon \\
\hline CRTN & 0.4323 & 0.5442 & 0.6436 & 0.8959 & 0.8473 & 0.7892 \\
\hline NMPB & 0.2764 & 0.3179 & 0.3505 & 0.7989 & 0.7412 & 0.7319 \\
\hline
\end{tabular}

\section{Assessing the noise conditions}

Figures 3, 4, 5 and 6 show the mapping of the noise levels measured in the two studied routes. It shows a tendency of noise increase in noon and afternoon periods and for the morning period it shows the lowest registered values. Table 3 shows the unhealthy noise ranges under which human activities are developed at Routes 1 and 2. The sound pressure levels are above the critical limit suggested by the Brazilian Association of Technical Standards, which is 60 (dB) (ABNT, 2019). When combining the equivalent continuous sound level $\mathrm{L}_{\text {Aeq }}$ with the noise climate $\mathrm{L}_{10}-\mathrm{L}_{90}$, which is implicit in $\mathrm{L}_{n p}$ index, it is also possible to verify the high ranges of values achieved. Along both routes, $\mathrm{L}_{\mathrm{np}}$ values above $85 \mathrm{~dB}$ were detected in a large number of points: 8 in morning, 15 in noon and 21 in afternoon period. In addition, $85 \mathrm{~dB}$ is considered the threshold between acceptable and unhealthy environments by regulatory norms NR-15 of the Ministry of Labor in Brazil. These results suggest that Routes 1 and 2 can be considered unhealthy for pedestrian exposure.

In Table 4 we can analyze the absolute error of the CRTN and NMPB prediction models. CRTN absolute error intervals were $\mathrm{L}_{\text {Aeq }}(0.14,8.37)$ and $\mathrm{L}_{\mathrm{np}}(0.12,9.91)$ and for NMPB absolute error intervals are $\mathrm{L}_{\text {Aeq }}(0.29$, $10.25)$ and $L_{n p}(0.00,10.83)$. In addition, the results of the correlation analysis between predictions and measurements are shown in Figures 7, 8, 9 and 10. These results suggest a good performance of the prediction methods and classify CRTN and NMPB as good tools to complement the vehicular noise control. However, the absolute error of about $10 \%$ may induce a high uncertainty that could be influential for specific applications. In our case, for example, we can consider that the CRTN and NMBP error margin was influenced by:

(a) the large variation of values recorded in the morning, noon and afternoon periods; and

(b) the topological structure of the city streets, which requires continuous acceleration of the vehicles and are not accounted for prediction methods.

In Table 5 it can be seen that CRTN has better performance than NMPB. Since CRTN had only one correlation value considered weak-correlation, $\mathrm{L}_{\text {Aeq }}(0.4323)$ in the morning period. In addition, CRTN correlation values to $\mathrm{L}_{\mathrm{np}}$ had great differential when compared to NMPB values. Thus, these results positioned the CRTN as a predicting method of better performance in our application.

Noise maps were developed, considering the $\mathrm{L}_{\mathrm{np}}$ values index of CRTN, shown in Figure 7.

These maps highlight the influence of the adjacent routes in the increase of traffic noise of the studied routes. Observing the areas extrapolating the reference control points themselves, it is possible to verify the sound sprawling around the routes. In these maps, the noise level around the routes is exclusively generated by the traffic along the routes studied. Thus, additional noise should be expected, if local traffic flow of the adjacent areas were also considered.

\section{Discussions: noise prediction in urban environments}

The noise descriptors here studied show that the users are exposed to excessive noise levels along the routes, as shown in the Figure 11, always achieving limits ranges above $60 \mathrm{~dB}$. These results confirm the noise threat on human health already detected for many other cities of the world (IBHADODE et al., 2018). The $\mathrm{L}_{\mathrm{np}}$ registered at the routes studied are comparable to the ranges found in Barcelona (LAGONIGRO; MARTORI; APPARICIO, 2018), vulnerable population groups. Considering that the city of São Carlos is a Brazilian midsized city and that Barcelona is a metropolis, this similarity on results should not be expected. This fact highlights the urgency on effective actions in Brazil and reinforces the importance of the prediction of mathematical models for an express support of planning actions for noise control. 
Figure 11 - Pollution noise indices map

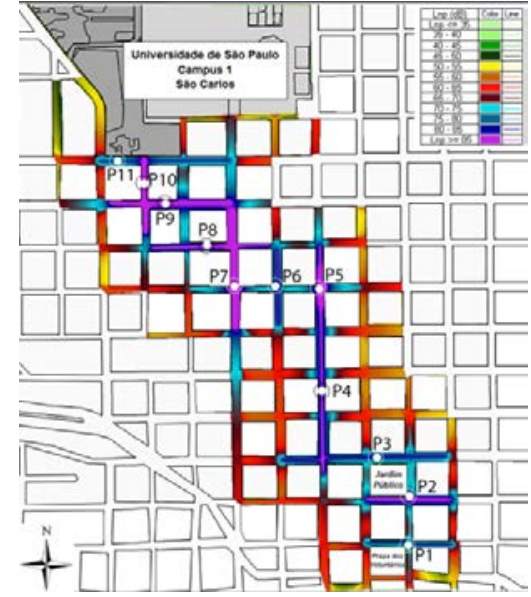

(A) Along Route 1

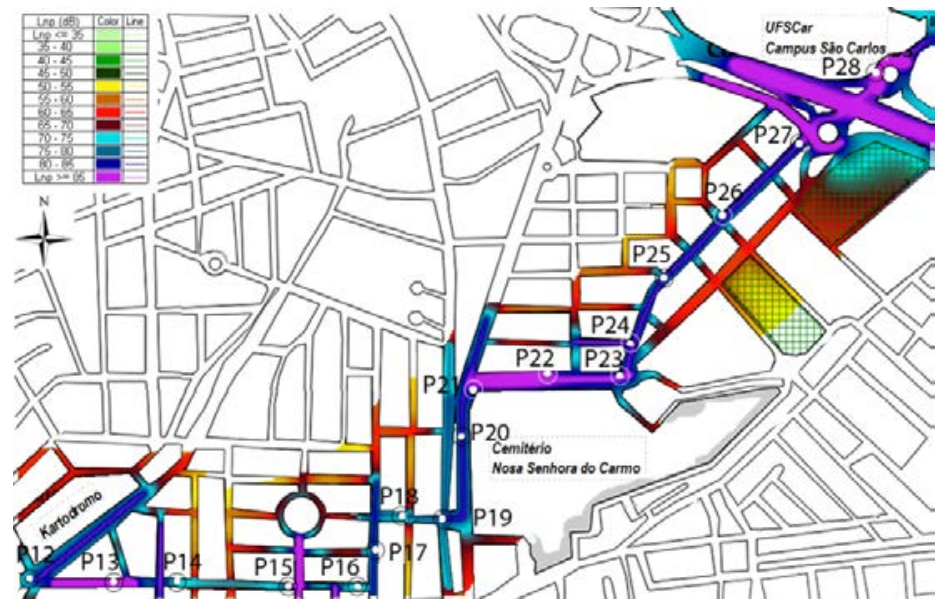

(b) Along Route 2

Figure 11 summarizes a combination of mathematical model applied to he development of noise maps. This combination will provide a solution for developing cities, which are still in a weak condition to reach an advanced stage of a continuous monitoring system. CRTN and NMPB models were found to be reliable for other authors (SHENG; XU; LI, 2015; MURPHY; DOUGLAS, 2018) and to allow the generation of complementary data. However, there are still many issues related to the development of noise maps, even for the European countries that already adopted them as a strategy for noise control (ABRAMIC et al., 2017).

Though being useful for decision makers, the dissemination of information about noise maps to the general public remains a challenge. At this point, a smart city technology could be helpful to provide data for common users. Furthermore, approaching the problem from the users' viewpoints could be a relatively promising strategy, though also requiring improvements on the current approaches already applied by developed countries (ABRAMIC et al., 2017).

Nowadays, users are always interested in having information about route conditions, in such a way that they usually access data with their mobile cells, either to be aware of the weather or for traffic information. Nonetheless, in cases where the basic information about the street noise is already unavailable, alternative solutions for online information should emerge.

The analysis of the two prediction models, studied here, plays an important role in the urban scenario of developing countries. The prediction models open opportunities when they provide the users with the access of what the noise conditions will be, for instance, the differences of calculated $\mathrm{L}_{\text {Aeq }}$ or $\mathrm{L}_{\mathrm{np}}$ between two points on a route are tips of what a user could expect of the noise environment. This way, when the user is already subjected to a certain noise level condition, the reference is the noise environment under which he is positioned at that moment. Therefore, being aware of the increase or the decrease of sound levels could be a way of expressing the quality of the environment expected in the arrival point or along the way. Additionally, the awareness of these conditions could probably influence on the route adopted.

Figure 12 shows some differences of $\mathrm{L}_{\text {Aeq }}$ measured values in the noon period, selected as an example, between the first point of the routes studied and the others. For the analysis of Route 1, point 1 was considered as the very beginning of the route, while for Route 2, point 12 was the beginning point.

Based on these differences, a user of Route 1 beginning a trip at point 1 identifies that he is positioned at one of the points with the lowest noise level of the route. So, if that point is already noisy, the others are expected to be even louder. If a 5dB-difference is considered as doubling the perception of sound level, then P2, P3, P5, and P7 should represent points to be avoided. By analogy, on Route 2, a user beginning a trip at point 12 could expect one place under better conditions along the route. Nonetheless, P15, P19 and P23 with differences of $5 \mathrm{~dB}$ should probably be avoided.

If these results of $\mathrm{L}_{\mathrm{Aeq}}$ differences are placed on a mobile app, in a friendly interface, the data could appear as labels on a map (similar to the online navigation maps functionality), flagging points that should be avoided. An example of this map, for Route 2, is placed on Figure 13. 
Figure 12 - Differences of noon period $L_{\text {Aeq }}$ measured in relation to the route's first point

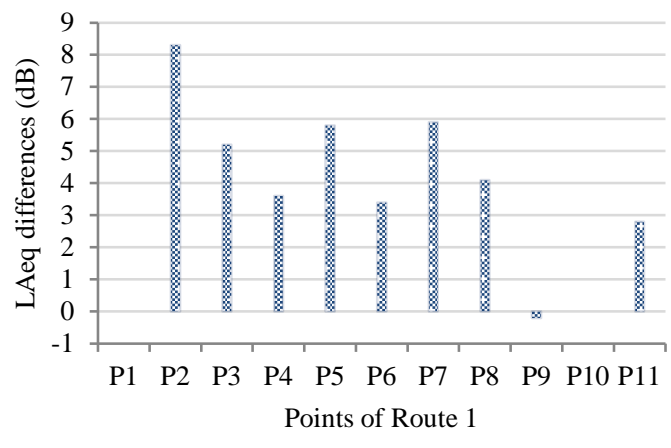

(a) Route 1

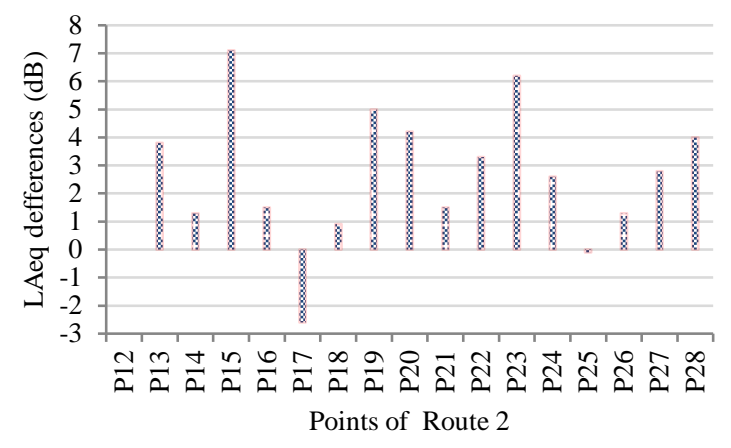

(b) Route 2

Figure 13 - Labels for warning noise conditions of Route 2, based in the Figure $\mathbf{1 2 b}$

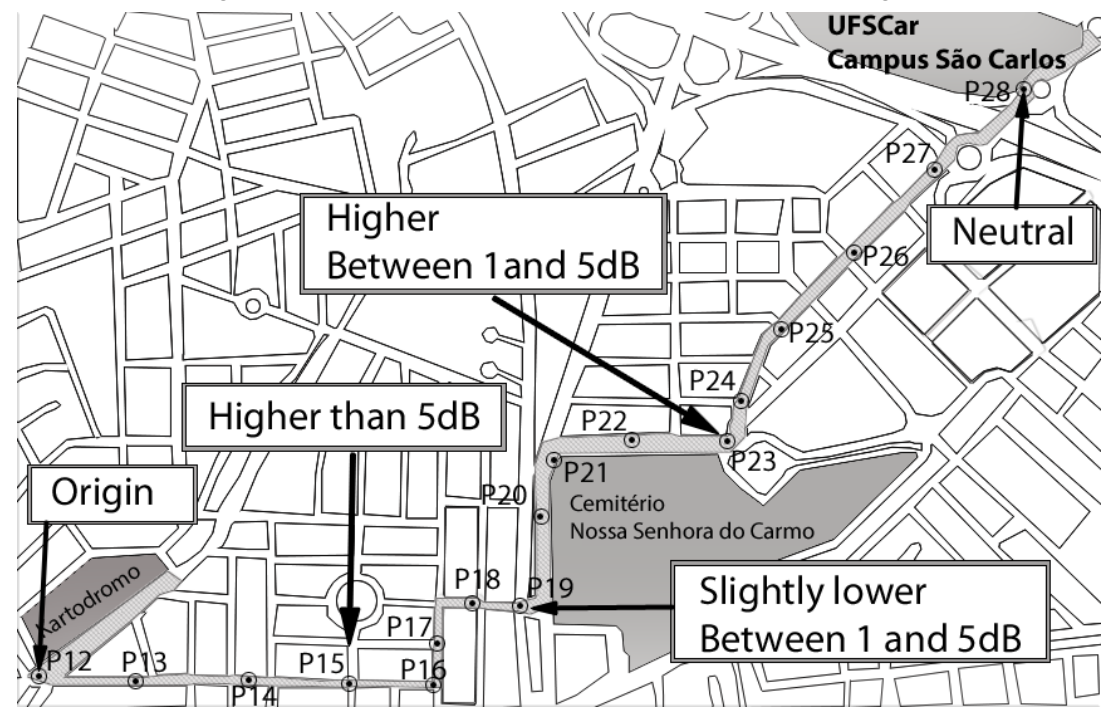

For the implementation of such a tool, in the absence of sensors for continuous monitoring of the sound environment, it would be necessary to:

(a) access the data basis of traffic flows and speeds, which are usually maintained by traffic management agencies;

(b) simulate the $\mathrm{L}_{\text {Aeq }}$ and $\mathrm{L}_{\mathrm{np}}$ values by mean of applying the CRTN or NMPB prediction model; and

(c) create a protocol of reading geographical positions and plotting them into a GIS-based mapping platform.

Thus, the dissemination of noise conditions through online information devices (responsive and reactive) could enhance the success of the planning actions, though regarding making clear for the users that there are limitations on the noise mapping, in order to create realistic expectations, as in the work of Kaddoura, Kröger and Nagel (2017).

\section{Conclusion}

In this study, we analyzed the sound pollution indices LAeq and Lnp generated by vehicular traffic, along two pedestrian routes. We monitored Twenty-eight points, so Route 1 had 11 and Route 2 had 17 points. We performed the measurements in a daytime section during 3 periods: morning, noon and afternoon. In addition, we analyzed the performance of CRTN and NMPB prediction models. As a final point, we constructed the noise map corresponding to each studied route, using the data calculated by the CRNT forecast model. 
We summarized the conclusions as follows:

(a) the vehicular traffic noise at all points monitored along Routes 1 and 2, in the three periods (7:00 to 8:00 morning, 11:30 to 12:30 noon, 17:30 to 19:00 afternoon), exceed the critical limit considered by local authorities $(60 \mathrm{~dB})$. In addition, we noticed that the vehicular traffic noise intensifies in the noon and afternoon periods, reaching severe limits (greater than $85 \mathrm{~dB}$ );

(b) the prediction models CRTN and NMPB performed well when compared to the measurements values. The largest absolute error recorded was of $10 \%$ which we considered a moderate value, taking into account mainly the large differential variation between the three collection periods (morning, noon and afternoon); and

(c) the CRTN prediction model had a better performance than the NMPB, the scoring parameters were the absolute error value and the correlation value compared to the measurement values. We consider that CRTN model is a good tool that can help or complement vehicular noise traffic monitoring.

\section{References}

ABRAMIC, A. et al. A spatial data infrastructure for environmental noise data in Europe. International Journal of Environmental Research and Public Health, v. 14, n. 7, p. 726, 2017.

AGARWAL, P. K. et al. some basic concepts for mitigating traffic noise. Journal of Advanced Research in Automotive Technology and Transportation System, v. 2, n. 3/4, p. 26-30, 2017.

ANCONA, C. et al. Health impact assessment of air pollution, noise, and lack of green in Rome. Journal of Transport \& Health, v. 5, n. S42-3, jun. 2017.

ANDERSON, G.; BARRETT, D. Supplemental Guidance on the Application of FHWA's Traffic Noise Model (TNM). The National Academies of Sciences, Engineering, and Medicine, Transportation research board, Washington U.S.A., n. 791, 110p, 2014.

ASSOCIAÇÃO BRASIELIRA DE NORMAS TÉCNICAS. NBR 10151: acoustics-measurement and evaluation of sound pressure levels in inhabited environments: application for general use. Rio de Janeiro, 2019.

BIES, D. A.; HANSEN, C. H. Engineering noise control: theory and practice. New York: CRC Press, 2009.

BRITO, L. A.; CARVALHO JUNIOR, J. B; TOLEDO, V. D. The efficiency of mathematical algorithms for urban noise evaluation. urbe. Revista Brasileira de Gestão Urbana, v. 10(1), pp. 22-35, Apr 2018.

CHANG, T. Y. et al. A modified Nordic prediction model of road traffic noise in a Taiwanese city with significant motorcycle traffic. Science of the Total Environment, v. 432, p. 375-381, ago. 2012.

DI, H. et al. Estimation of the quality of an urban acoustic environment based on traffic noise evaluation models. Applied Acoustics, v. 141, p. 115-124, dec. 2018.

DOT UK. Department of Transport. Calculation of Road Traffic Noise (CRTN). London: Department of Transport, Welsh Office, HMSO, 1988.

DUTILLEUX, G. et al. NMPB-ROUTES-2008: the revision of the French method for road traffic noise prediction. Acta Acustica united with Acustica, v. 96, n. 3, p. 452-462, may 2010.

HUNASHAL, R. B.; PATIL, Y. B. Assessment of noise pollution indices in the city of Kolhapur, India. Procedia-Social and Behavioral Sciences, v. 37, p. 448-457, jan. 2012.

IBHADODE, O. et al. Assessment of noise-levels of generator-sets in seven cities of South-Southern Nigeria. African Journal of Science, Technology, Innovation and Development, v. 10, n. 2, p. 125-135, fev. 2018.

INSTITUTO BRASILEIRO DE GEOGRAFIA E ESTATÍSTICA. Year: 2018. Available from: www.ibge.gov.br. Accessed: 8 Aug. 2018.

ISO 1996, INTERNATIONAL ORGANIZATION FOR STANDARDIZATION. Acoustics: Description and measurements of environmental noise. Part 1: Basic quantities and procedures, 1996-1. Switzerland, pp. 5 1996. 
KADDOURA, I.; KRÖGER, L.; NAGEL, K. User-specific and dynamic internalization of road traffic noise exposures. Networks and Spatial Economics, v. 17, n. 1, p. 153-172, mar. 2017.

LAGONIGRO, R.; MARTORI, J. C.; APPARICIO, P. Environmental noise inequity in the city of Barcelona. Transportation Research Part D: Transport and Environment, v. 63, p. 309-319, ago 2018.

MÜNZEL, T. et al. Environmental noise and the cardiovascular system. Journal of the American College of Cardiology, v. 71, n. 6, p. p. 688-697, fev. 2018.

MURPHY, E.; DOUGLAS, O. Population exposure to road traffic noise: experimental results from varying exposure estimation approaches. Transportation Research Part D: Transport and Environment, v. 58, p. 70-79, jan. 2018.

NIEUWENHUIJSEN, M. J. Influence of urban and transport planning and the city environment on cardiovascular disease. Nature Reviews Cardiology, v. 13, p. 1, abr. 2018.

PÉREZ LÓPEZ, G. A.; SOUZA, L. C. Urban green spaces and the influence on vehicular traffic noise control. Ambiente Construído, Porto Alegre, v. 18, n. 4, p. 161-175, out./dez. 2018.

PEREZ, G.; PENTEADO, D.; SOUZA, L. The effect of environmental characteristics of cities on urban noise. In: PLEA: DESIGN TO THRIVE, 33., Edinburgh, 2017. Proceedings [...] Edinburgh, 2017.

SAKAMOTO, S. Road traffic noise prediction model “ASJ RTN-Model 2013”: Report of the Research Committee on Road Traffic Noise. Acoustical Science and Technology, v. 36, n. 2, p. 49-108, fev. 2015.

SHENG, N.; TANG, U. W. Spatial techniques to visualize acoustic comfort along cultural and heritage routes for a world heritage city. Sustainability, v. 7, n. 8, p. 10264-10280, jul. 2015.

SHENG. N.; XU, Z.; LI, M. The performance of CRTN model in a motorcycle city. Mathematical Problems in Engineering, v. 2015, p. 1-7, 2015.

SUN, K. et al. Effect of interaction between attention focusing capability and visual factors on road traffic noise annoyance. Applied Acoustics, v. 134, p. 16-24, may 2018.

VAN SCHALKWYK, M. C.; MINDELL, J. S. Current issues in the impacts of transport on health. British medical bulletin, Publisher Oxford University Press, v. 125, n. 1, p. 67-77, mar. 2018.

ZHANG, X. et al. The research on application of cadna/a software in noise prediction of urban substation. DEStech Transactions on Engineering and Technology Research, 3rd International Conference on Engineering Technology and Application (ICETA 2016), Pennsylvania, U.S.A., p. 541-545, 2016.

\title{
Acknowledgments
}

This research was supported by Coordination for the Improvement of Higher Education Personnel (CAPES).

\section{Guillermo Angel Perez Lopez}

Núcleo de pesquisa em acústica e térmica nas edificações e redes viárias, Laboratório de Conforto e Eficiência Energética no Ambiente construído, Departamento de Engenharia Civil | Universidade Federal de São Carlos | Av. Prof. Mello Moraes, 2373, Butantã | São Paulo SP - Brasil | CEP 05508-030 | Tel.: (11) 3091-5151 | E-mail: guillermo.angel@usp.br

\section{Léa Cristina Lucas de Souza}

Centro de Ciências Exatas e de Tecnologia | Universidade Federal de São Carlos | Rodovia Washington Luis, km 235, Monjolinho | São Carlos - SP - Brasil | Caixa Postal 676 | CEP 13565-905 | Tel.: (16) 3351-9692 | E-mail: leacrist.ufscar@gmail.com

\author{
Ambiente Construído \\ Revista da Associação Nacional de Tecnologia do Ambiente Construído \\ Av. Osvaldo Aranha, 99 - 3o andar, Centro \\ Porto Alegre - RS - Brasil \\ CEP 90035-190 \\ Telefone: +55 (51) 3308-4084 \\ Fax: +55 (51) 3308-4054 \\ www. seer. ufrgs. br/ ambienteconstruido \\ E-mail: ambienteconstruido@ufrgs.br
}

